\title{
蛍光偏光免疫測定法におけるジゴキシン様物質の発生と光散乱の関与
}

\author{
青野珠可, 河上直美, 加藤 敦, 川上純一* , 足立伊佐雄 \\ 富山医科薬科大学附属病院薬剤部门
}

\section{Appearance of Digoxin-like Factor and Implication of Scattering-light in Fluorescence Polarization Immunoassay}

\author{
Shuka Aono, Naomi Kawakami, Atsushi Kato, Junichi Kawakami* and Isao Adachi \\ Department of Hospital Pharmacy, Toyama Medical and Pharmaceutical University $\dagger$
}

$\left[\begin{array}{ll}\text { Received September 4, } 2000 \\ \text { Accepted December 10, } 2000\end{array}\right]$

Digoxin-like factor (DLF) is known to interfere with a digoxin assay and falsely elevate the digoxin concentration. DLF has been reported in patients with liver and renal diseases, terminal pregnant women and infants. In this study, cholestasic rats induced by a surgical bile-duct ligation were used to clarify the appearance of DLF in a fluorescence polarization immunoassay (FPIA), and finally a precipitation method was improved. DLF increased immediately and reached about $0.4 \mathrm{ng} / \mathrm{mL}$ at $48 \mathrm{hrs}$ after the bile-duct ligation. After centrifugal deproteinization with a precipitation reagent, $6 \%$ sulfosalitylic acid aq. solution : MeOH mixture ( $1: 1)$ (SSA), 69 and $202 \mu \mathrm{g}$ of a residue were detected while using a membrane filter (cellulose acetate ; pore size, $0.45 \mu \mathrm{m})$ at room temperature for 20 and $60 \mathrm{~min}$, respectively. The scattering-light intensity $(480-490 \mathrm{~nm})$ of the cholestasic plasma was 5.5 times higher than that of the normal plasma and moreover increased by $20 \%$ after $60 \mathrm{~min}$ of incubation at room temperature. However, this high scattering-light intensity diminished when kept at $4^{\circ} \mathrm{C}$ for $60 \mathrm{~min}$ after adding the precipitation reagent, and DLF could thus be reduced. Porphyrin, a mixture of bilirubin and urobirin, can easily be aggregated by increasing the ionic strength and acidity, therefore, the addition of $\mathrm{NaCl}$ into cholestasic plasma in order to elevate the ionic strength potentiated the scattering-light intensity and DLF. These findings suggested that DLF in the cholestasic plasma may arise as a result of the appearance of some large particles after centrifugation because of insufficient deproteinization, which can scatter excited light due to polarization.

Keywords — fluorescence polarization immunoassay (FPIA), digoxin like factor (DLF), digoxin-like immunoreactive factor (DLIF), cholestasis, scattering-light

\begin{abstract}
緒言
血漿中ジゴキシン濃度の測定法には HPLC や RIA を 用いた方法があるが，操作性や，迅速性などの観点から 臨床においては蛍光偏光免疫測定法 (FPIA), マイクロ パーティクル酵素免疫測定法（MEIA）抒よび化学発光 免疫測定法などが一般的に使用されている1-3). しか
\end{abstract}

し, 腎機能障害患者, 肝機能障害患者, 妊娠後期の妊 婦，新生児などの血中に，ジゴキシンの投与を受けてい ないにもかかわらず，測定上ジゴキシンが検出されるこ とがある.このような現象は，血中にジゴキシン抗体と 反応する物質が存在するためと考えられており，これを ジゴキシン様物質（DLF； Digoxin Like Factor）と呼んで いる，DLFはFPIAに打いて最も多く報告されてお 


\section{3. 試薬}

コントロールの血漿にジゴキシン（Aldrich Chemical Co., USA）を加え, ジゴキシン濃度が0.5-1.0ng/mL に なるように調整した。

\section{DLF またはジゴキシンの血漿中濃度の測定}

DLFまたはジゴキシンの血漿中濃度の測定は, FPIA によるジゴキシン測定キット（TDX ${ }^{\mathrm{TM}}$ ージゴキシン「ア ボット」；ダイナボット，東京）を用い, TDXアナライ ザー（ダイナボット）にて測定した（検出限界は0.2ng/ $\mathrm{mL})$. 除タンパク剂には測定キットに付属する $3 \% 5-$ スルホサリチル酸を含む50\%メタノール水溶液（SSA） を用いた。また除タンパク操作は，測定試薬キットの添 付文書に記載されている方法 (通常操作, standard method）に従って行った。すなわち TDX 遠心用チュー

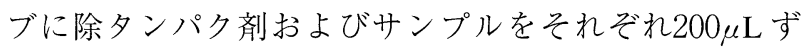
つ分注し，遠心チューブのふたをし，3〜5秒間サンプ ルミキサーで擋拌した後, 約 90 秒間遠心分離して透明な 上清を得た。

\section{5. 胆汁うっ帯ラットにおける DLF の測定}

コントロールと胆汁うっ滞のラットから，胆管結禁 前, 結㮃後 $4,8 ， 12 ， 24 ， 48$ 時間に，軽いエーテル麻 酔下, 眼底静脈より血液 $500 \mu \mathrm{L}$ を採取し, FPIAにて血 漿中のDLFを測定した。

\section{6. ラット血漿の採取}

偽手術終了後または胆管結禁48時間後，コントロール と胆汁うっ滞ラットの下行大動脈より採血し, 遠心分離 $(1,000 \times \mathrm{g}, 10 \mathrm{~min})$ によって血漿を得た。採取した血 漿はただちにー $20^{\circ} \mathrm{C} て ゙$ 測定時まで保存した。

\section{DLF と除タンパク時間, 温度の関係}

胆管結禁48時間後のラットの血漿 $200 \mu \mathrm{L}$ と, 既知量 (約 $0.75 \mathrm{ng} / \mathrm{mL})$ のジゴキシンを添加したコントロール

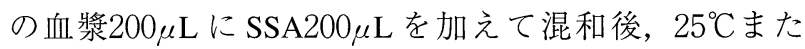
は $4{ }^{\circ} \mathrm{C} に て 1 ， 4 ， 8$ 時間放置した。 TDX 専用遠心分 離器にて遠心分離した後 $(9,500 \times \mathrm{g}, 90 \mathrm{sec})$ ，ただちに FPIAにて上清中の見かけのジゴキシン濃度を測定し た.

\section{8. メンブランフィルターによるろ過}

胆管結紮 48 時間後のラットの血漿 $200 \mu \mathrm{L}$ と, 既知量 のジゴキシンを添加したコントロールの血漿 $200 \mu \mathrm{L}$ に, SSAを $200 \mu \mathrm{L}$ 添加した. 混和後, ただちに TDX 専 用遠心分離器にて遠心分離 $(9,500 \times \mathrm{g}, 90 \mathrm{sec})$ L, そ 
の上清を $0 ， 10 ， 20 ， 30 ， 60$ 分間室温で放置した後，そ のうち $300 \mu \mathrm{L}$ をメンブランフィルター (cellulose acetate, pore size $0.45 \mu \mathrm{m})$ に通した。フィルターを 2 日間 $25^{\circ} \mathrm{C}$ で乾燥後，その重量をマイクロ天秤にて測定し，フィル ター上の残存重量を算出した。

\section{9. 光散乱スペクトルの測定}

胆管結紮48時間後のラットの血漿 $200 \mu \mathrm{L}$ と，既知量 のジゴキシンを添加したコントロールの血漿 $200 \mu \mathrm{L}$ に SSA $200 \mu \mathrm{L}$ 添加した。混和後, ただちに TDX 専用遠 心分離器にて遠心分離 $(9,500 \times \mathrm{g}, 90 \mathrm{sec})$ を行った. 遠心分離の直後または60分間室温で放置した上清を TDX 希釈㣪衝液（ダイナボット）で10倍希釈し，たた ちに蛍光分光光度計 (RF-5300PC; 島津製作所, 東京) を用い，光散乱スペクトル（400-600nm）を測定した. またSSAを添加してから水冷中で60分間放置した後, 遠心分離により得た上清についても同様に光散乱スペク トルを測定した。スペクトルの測定には，励起波長と検 出波長が同じ波長（バンド幅1.5nm）で移動しながらス キャンする synchronous scan modeを用いた。

\section{DLF および散乱光強度に及ぼす $\mathrm{NaCl}$ 添加の影響}

Pasternack らの方法に準じて ${ }^{12)}$, DLF および散乱光強 度におよぼす $\mathrm{NaCl}$ 添加の影響を調べた。すなわち，胆 汁うっ滞㧍よびコントロールの血漿に, $\mathrm{NaCl}$ (ナカラ イテスク，東京）を添加し，ポルフィリンが集合体を形 成する $1.5 \% に \mathrm{NaCl}$ 濃度を調整した。コントロール群 には $\mathrm{NaCl}$ 溶液の代わりに蒸留水を加えた。これらの血 漿 $200 \mu \mathrm{L}$ に SSA を $200 \mu \mathrm{L}$ 添加して混和後, ただちに遠 心分離 $(9,500 \times \mathrm{g}, 90 \mathrm{sec})$ して，上清を得た。その後， DLFを FPIA により測定した．さらに光散乱スペクトル の実験と同様の方法で，胆汁うっ滞とコントロールの血 漿について $\mathrm{NaCl}$ 添加・非添加時の光散乱スペクトルを それぞれ測定した。

\section{1. 承冷下除タンパク操作の有用性}

胆汁うっ滞抢よびコントロールの血漿に0，0.5, 1.0, $2.0 \mathrm{ng} / \mathrm{mL}$ となるようにジゴキシンを添加した．各血漿 $200 \mu \mathrm{L}$ に氷冷した SSA を $200 \mu \mathrm{L}$ 加え混和後, 水冷にて 1 時間放置し，遠心分離 $(9,500 \times \mathrm{g} ， 90 \mathrm{sec})$ を行い上 清の見かけのジゴキシン濃度を FPIAにより測定した。

また，ジゴキシンの投与を受けていないヒトの血清 を， $4{ }^{\circ} \mathrm{C} て ゙ 1$ 時間の除タンパク操作を行い DLFを FPIA により測定した。

\section{2. 統計処理}

対照群との有意差検定は $\mathrm{F}$ 検定により等分散性が確 認されたため, 対応のないStudent's $t$-test にて行い, $\mathrm{p}<$ 0.05をもって有意差ありと判定した。

\section{結果}

\section{1. 胆汁うつ滞の DLF に与える影響}

ジゴキシンを含んでいないにも関わらず，FPIAによ りジゴキシン濃度として検出された值をDLFとした。 胆管結紮後の血漿中 DLFの推移を Fig. 1 に示した。胆 管結紮 4 時間後にはDLF の上昇がみられ，48時間後で 約 $0.45 \mathrm{ng} / \mathrm{mL}$ を示した。一方，コントロールではすべ ての点が $0.2 \mathrm{ng} / \mathrm{mL}$ 以下であった。これにより，胆汁 うっ滞の血漿中にはDLFが存在し, ジゴキシン測定值 が実際よりも高くなることを確認した。

\section{DLF と除タンパク時間, 温度の関係}

SSA を添加後一定時間放置し遠心したときの，DLF 濃度の経時的変化を測定した.ジゴキシンを含むコント ロールの血漿では，放置時間，温度に関係なく約 0.75 $\mathrm{ng} / \mathrm{mL}$ で，変動は測定誤差の範囲であった（デー夕示 さず)。一方，胆汁うっ滞の場合，DLF 值は時間依存的 に減少し，また $4{ }^{\circ} \mathrm{C} て ゙$ 除タンパク操作を行うと DLFは さらに低下した（Fig. 2).

\section{3. フィルター残存重量の経時的変化}

胆汁うっ滞ラットとコントロールの血漿を SSAにて 除タンパクした後, 上清をメンブランフィルターでろ過 した.フィルター残存重量の経時的变化を Fig. 3 に示 す. 胆汁うっ滞ラットの血漿においては，フィルター上 の残存重量は時間依存的に増加し, 室温で 1 時間放置す ることにより $202 \mu \mathrm{g}$ 増加していた。一方ジゴキシンを添 加したコントロールの血漿では, 残存重量の増加はみら れなかった。

\section{4. 光散乱スペクトルの測定}

室温扔よび氷冷下に执いて除タンパク操作を行った血 漿の400-600nmにおける光散乱スペクトルを Fig. 4 に，また FPIA の励起波長付近（480-490nm）における 散乱強度下面積を Table 1 に示す．胆汁うっ滞の血漿に 除タンパク剤を加えて遠心し，その上清を室温で 1 時間 放置すると，光散乱は上昇した。480-490nm の散乱強 度下面積も，室温で 1 時間放置することにより約 $20 \%$ 増 加した，一方，胆汁うっ滞の血漿に除タンパク剤を加え て， $4{ }^{\circ} \mathrm{C} て ゙ 60$ 分間放置した後，遠心して得た上清の光散 乱スペクトルは，コントロール近くまで低下し，480- 


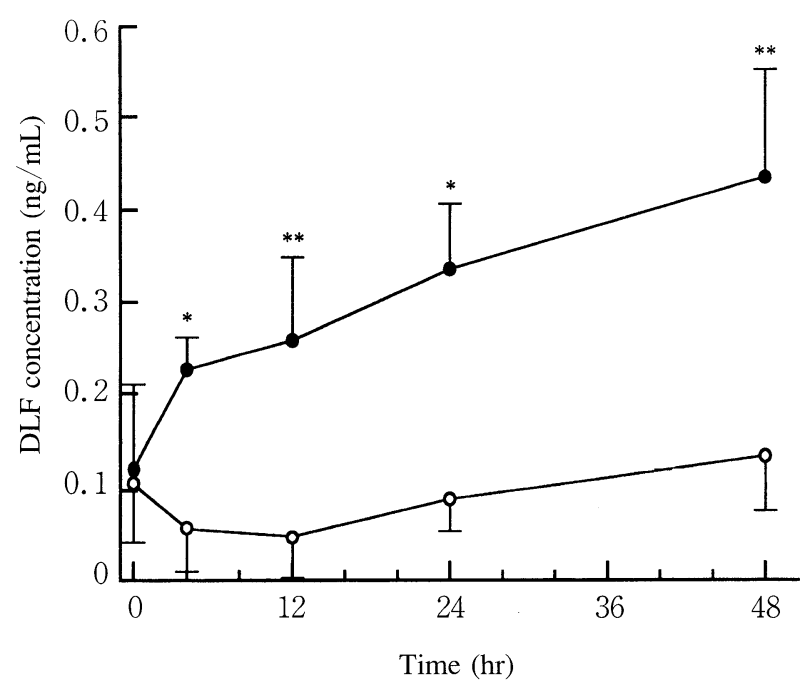

Fig. 1. Changes of DLF Concentration in the Plasma of Cholestasic (closed circle) and Control (open circle) Rats Measured by FPIA.

Each value represents mean \pm SD of $3-5$ rats.

${ }^{*}$ Significant different from the control $(\mathrm{p}<$ 0.01 )

* Significant different from the control $(\mathrm{p}<$ 0.05)

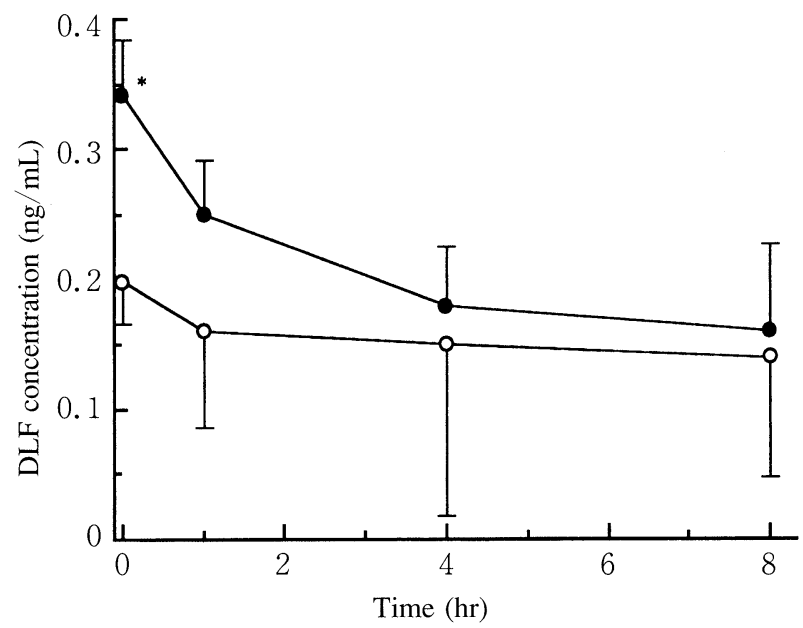

Fig. 2. Decrease in DLF of Cholestasic Plasma Precipitated at $4{ }^{\circ} \mathrm{C}$ (open circle) and $25^{\circ} \mathrm{C}$ (closed circle).

Each value represents mean \pm SD of 3 rats.

* Significant different from the control $(\mathrm{p}<$ $0.05)$

490nm における散乱強度も，通常操作を行った場合と 比べて $72 \%$ 減少させることができた。コントロールで は，どの除タンパク条件においても大きな散乱強度の上 昇はみられなかった。

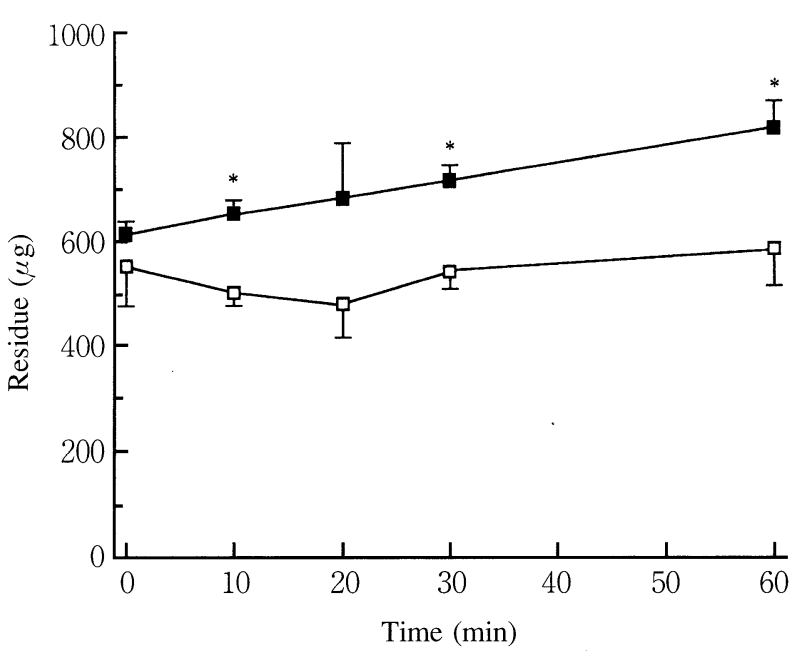

Fig.3. Residue Amount of Cholestasic (closed square) and Normal (open square) Plasma Samples After SSA Precipitation.

Each value represents mean $\pm S D$ of 3 data.

* Significant different from the control $(\mathrm{p}<0.01)$

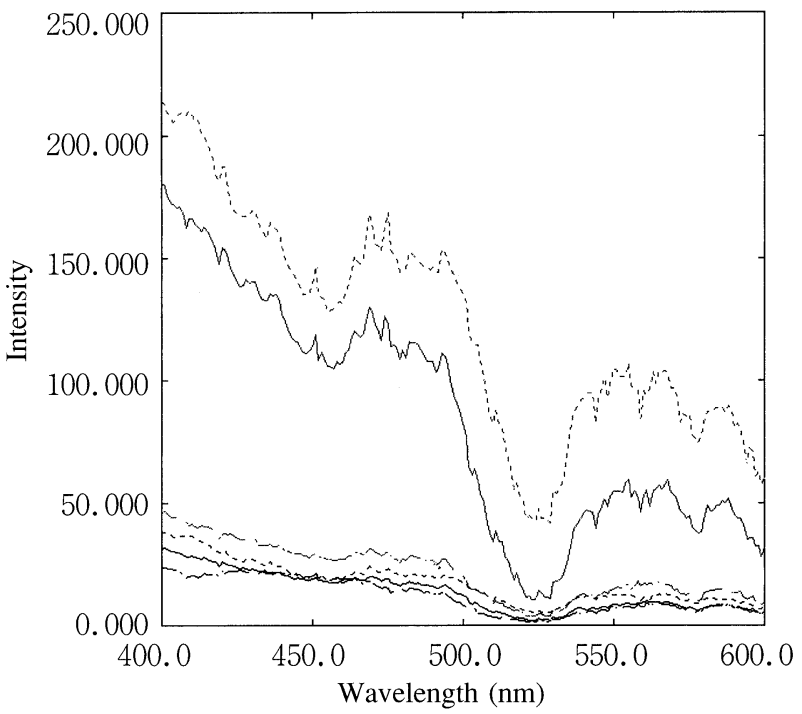

Fig. 4. Scattering-Light Spectrum of Cholestasic and Normal Plasma Samples after SSA Precipitation.

Spectra are not corrected for photomultiplier respon

... ... .... Cholestasis : precipitated after incubation at $25^{\circ} \mathrm{C}$ for $60 \mathrm{~min}$.

Cholestasis : precipitated after incubation at $25^{\circ} \mathrm{C}$ for $0 \mathrm{~min}$.

Cholestasis : precipitated after incubation at $4^{\circ} \mathrm{C}$ for $60 \mathrm{~min}$.

- - - - Normal : precipitated after incubation at $25^{\circ} \mathrm{C}$ for $60 \mathrm{~min}$.

- Normal : precipitated after incubation at $25^{\circ} \mathrm{C}$ for 0 min.

- Normal : precipitated after incubation at $4^{\circ} \mathrm{C}$ for $60 \mathrm{~min}$. 
Table 1. Scattering-light Intensity Area (480-490 nm) of Supernatant Prepared from Cholestasic and Normal Plasma by the Standard and Modified Methods.

\begin{tabular}{lccc}
\hline & \multicolumn{3}{c}{ Scattering-light intensity area (intensity · area) } \\
\cline { 2 - 4 } & $\begin{array}{c}25^{\circ} \mathrm{C}, 0 \mathrm{~min} \\
\text { (standard method) }\end{array}$ & $\begin{array}{c}25^{\circ} \mathrm{C}, 60 \mathrm{~min} \\
\text { (modified method) }\end{array}$ & $\begin{array}{c}4^{\circ} \mathrm{C}, 60 \mathrm{~min} \\
\text { (modified method) }\end{array}$ \\
\hline Cholestasis & $1032.7 \pm 457.4$ & $1229.6 \pm 574.2$ & $292.5 \pm 111.3$ \\
\hline Normal & $188.2 \pm 44.0$ & $279.7 \pm 64.4^{*}$ & $131.5 \pm 57.8$ \\
\hline
\end{tabular}

Each value represents mean \pm SD of 6 data.

${ }^{*}$ Significant different from the standard method $\mathrm{P}<0.01$.

* Significant different from the standard method $\mathrm{P}<0.05$.

\section{DLF および散乱光強度に及ぼす $\mathrm{NaCl}$ 添加の影響}

FPIA：イオン強度を上昇させる目的で $\mathrm{NaCl}$ を添加し た胆汁うっ滞とコントロールの血漿において，DLFを FPIA により測定した結果を Fig. 5 に示す.コントロー ルの場合， $\mathrm{NaCl}$ を添加しても DLF は上昇せず，低值で あった。一方，胆汁うっ滞の場合， $\mathrm{NaCl}$ を添加するこ とによりDLFの上昇が見られた。コントロールと胆汁 うっ滞の血漿に $\mathrm{NaCl}$ を添加したときの DLFの平均上昇 度はそれぞれ，-0.035（ng/mL：ジゴキシンとして） および $0.123(\mathrm{ng} / \mathrm{mL}$ : ジゴキシンとして) であり，胆 汁うっ滞の血漿はコンロールに比べ有意に（P<0.05） 上昇した。

散乱光の測定： $\mathrm{NaCl}$ を添加，または無添加の胆汁 うっ滞とコントロールの血漿の光散乱スペクトルを

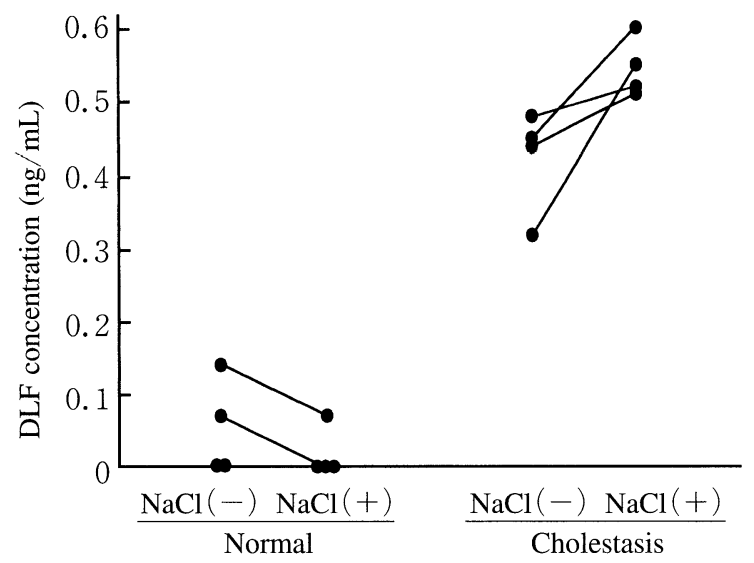

Fig. 5. Effect of $\mathrm{NaCl}$ on DLF Concentration in Cholestasic and Normal Plasma.

Each point represents one datum and each line represents changes of data.
Fig. 6 にまた480-490nm における散乱強度下面積を Table 2 に示す.コントロールの場合, $\mathrm{NaCl}$ を添加す ることにより光散乱スペクトルは上昇し，480-490nm における散乱強度は25\%増加した。また胆汁うっ滞の場 合も, $\mathrm{NaCl}$ を添加することにより, 光散乱スペクトル は上昇し，480-490nmにおける散乱強度も31\%増加し た。しかし散乱強度レベルは胆汁うっ滞の方が高くコン

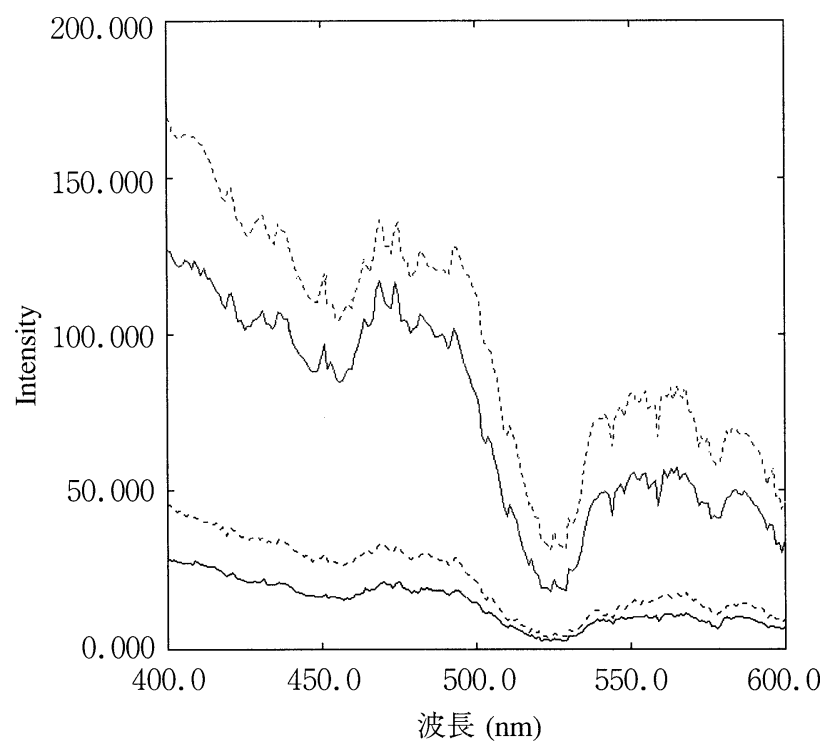

Fig. 6. Effect of $\mathrm{NaCl}$ on Scattering-light Spectrum of Cholestasic and Normal Plasma after Precipitation.

Spectra are not corrected for photomultiplier response.

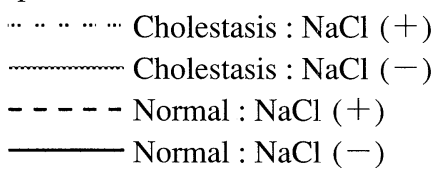


Table 2. Effect of $\mathrm{NaCl}$ on Scattering-light Intensity (480-490 nm) of Supernatant Prepared from Cholestasis and Normal Plasma.

\begin{tabular}{ccc}
\hline & \multicolumn{2}{c}{ Scattering-light intensity area (intensity -area) } \\
\cline { 2 - 3 } & $\mathrm{NaCl}(-)$ & $\mathrm{NaCl}(+)$ \\
\hline Cholestasis & $638.8 \pm 277.1$ & $837.4 \pm 353.0$ \\
\hline Normal & $253.3 \pm 52.0$ & $317.5 \pm 106.5$ \\
\hline
\end{tabular}

Each value represents mean \pm SD of 3 data.

トロールの2.6倍であった。

\section{6. 水冷下除タンパク操作の有用性}

胆汁うっ滞およびコントロールの血漿にジゴキシンを 添加し，通常操作を行った時と，水冷下で除タンパク操 作を行った時の見かけのジゴキシン濃度を比較した。添 加したジゴキシン濃度と見かけのジゴキシン濃度の相関 を Fig. 7 に示す. 通常操作の場合, 胆汁うっ滞とコン トロールの直線は，DLFの影響を受け平行になった。 しかし，水冷で 1 時間放置後に遠心することにより，両 者の直線は，ほぼ同一直線上に重なりDLFの影響を減 弱させることができた。
また，ジゴキシン投与を受けていないヒトの検体にお いてもDLFの影響を減少させることができた（Table 3). しかし $4{ }^{\circ} \mathrm{C} て ゙ 60$ 分間のインキュベーションを行っ ても DLF を完全には除去することはできず，0.29-0.48 $\mathrm{ng} / \mathrm{mL}$ の減少にとどまった.

\section{考察}

われわれのこれまでの実験結果より，胆汁うっ滞ラッ トにおけるDLFの出現には血漿中の光散乱が影響して いると考えられる，胆汁うっ滞の血漿では，時間依存的 にフィルターの膜を通過できないような微粒子が生成し ており，この微粒子は除タンパク処理後20分間放置する ことにより $69 \mu \mathrm{g}$ も増加した。 $\mathrm{TDX}^{\mathrm{TM}}$ アナライザーでジ ゴキシンを測定するには20分程度の時間が必要であり， 除タンパク処理した検体をカートリッジに注入した後に 析出してしまう微粒子によって，励起光の散乱が増大す ると考えられる. $\mathrm{NaCl}$ を添加し溶液中のイオン強度を 上昇させると，ポルフィリンの集合体が形成しやすくな り光散乱が上昇することが報告されている ${ }^{12)}$. 胆汁うっ 滞時には血中にビリルビンやウロビリンなどのポルフィ ン構造を持つ物質が多く存在しており，ポルフィリンが 集合体を形成しやすい状態にあると考えられる。 $\mathrm{NaCl}$ の添加により，散乱強度とともにDLFが上昇したこと からも，DLFの発生原因として光散乱物質が考えら
(A) Standard method

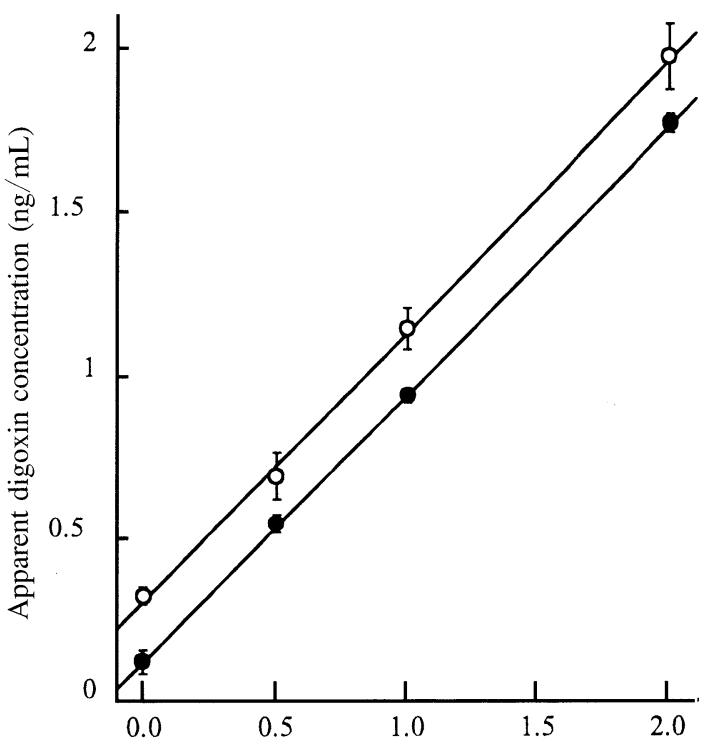

(B) Improved method ( $\left.4{ }^{\circ} \mathrm{C}, 60 \mathrm{~min}\right)$

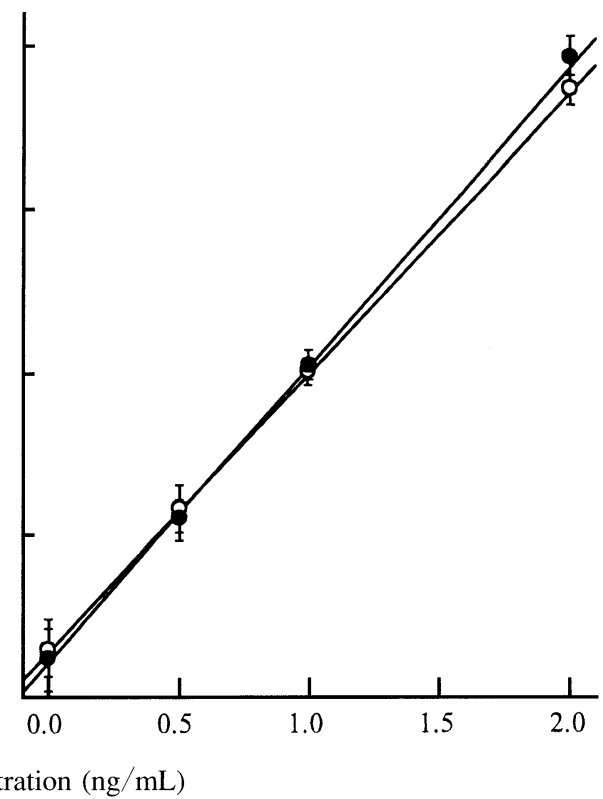

Fig. 7. Apparent Digoxin Concentration after the Standard Method (A) and Improved Method (B) at $4{ }^{\circ} \mathrm{C}$ for $60 \mathrm{~min}$.

Open circles and closed circles represent cholestasic and normal plasma, respectively. 
Table 3. DLF Concentration in Human Sera after the Standard and the Improved Method.

\begin{tabular}{|c|c|c|}
\hline \multirow[b]{2}{*}{ patients } & \multicolumn{2}{|c|}{ DLF concentration $\quad(\mathrm{ng} / \mathrm{mL})$} \\
\hline & $\begin{array}{l}25^{\circ} \mathrm{C}, 0 \mathrm{~min} \\
\text { (standard method) }\end{array}$ & $\begin{array}{c}4^{\circ} \mathrm{C}, 60 \mathrm{~min} \\
\text { (improved method) }\end{array}$ \\
\hline $\begin{array}{c}15 \text { years man } \\
\text { epilepsy }\end{array}$ & 0.69 & 0.21 \\
\hline $\begin{array}{c}63 \text { years man } \\
\text { hepatocirrhosis }\end{array}$ & 0.79 & 0.50 \\
\hline $\begin{array}{c}59 \text { years man } \\
\text { hepatocirrhosis }\end{array}$ & 0.53 & 0.19 \\
\hline
\end{tabular}

れ，その一つにポルフィリンなどの集合体が関与してい ると推測される。一方で, DLFを含む患者の血清を $4{ }^{\circ} \mathrm{C}$ で 1 時間の除タンパク処理を行ってもDLFを完全 には除去することができなかったことは，光散乱以外の DLFが存在している可能性も示唆しており，これらに ついてはさらなる検討が必要である。

除タンパク後に析出する光散乱物質は, 血漿に除タン パク剂を加え氷冷中で 1 時間放置してから遠心すること により，効果的に除去することができる．水冷下の除夕 ンパク操作は, 通常行っている除タンパク操作を部分的 に改善するだけで, 特別な試薬, 煩雑な操作も必要な く, DLFを減少させることができ有用な方法であると 考えている。そして Fig. 7 の結果から, 光散乱による DLF はジゴキシンの添加濃度に関係なく, 一定の見か け濃度の上昇をおこしている。このことから, 胆汁うっ 滞ラットにおけるDLFにはジゴキシン抗体に反応する 免疫様物質の影響はないと考えられる。

ジゴキシンの血漿中濃度を測定する場合, 治療域が 0.8 - $2.0 \mathrm{ng} / \mathrm{mL}$ と低く ${ }^{13)}$, FPIA で測定している他の薬 凨に比べ非常に高い感度を必要とする。このため大量の 検体を少ない希釈倍率で用いたり，ジゴキシンと抗体を あらかじめ小容量のカートリッジ内でインキュベーショ ンした後, トレーサーを添加するといった一連の操作を 行うことにより感度を高めている ${ }^{14)}$.しかしこれらの 操作は逆に，光散乱の原因となりうる集合体を形成する 時間を与えることになり, 集合体の形成を促進させる要 因となりうる，さらに検体の希釈倍率が小さいため，希 釈緩衝液の緩衝作用が期待できず，除タンパク剂である スルホサリチル酸の影響を強く受けてしまう。肝障害や 胆道疾患ではビリルビンなどのポルフィリンが血中に多 く存在しているが，ポルフィリンは酸性条件下において 集合体を形成しやすいという性質を持つことから ${ }^{15)}$, 光 散乱の原因物質の一つとも推測される。光散乱による DLF 值の上昇は FPIA 独特のものであり, ジゴキシンを
抗体に結合させた後, 洗浄過程がある MEIAなどでは おこらない.そしてこのことはFPIAにおいてDLFの 報告が多い理由の 1 つであると考えられる。

以上より，胆汁うっ滞ラットにおけるDLFの上昇 は, 不十分な除タンパク操作のために遠心後析出してし まう微粒子による光散乱であると考えられる。これまで DLF は，ジゴキシン抗体との交差性のためにジゴキシ ンの血中濃度を見かけ上高くしてしまうと考えられてき た。しかし，今回のわれわれの研究において，交差性以 外の光散乱によってDLFが出現しうることを示したこ とは新しい知見であり，またその改善方法を提案できた ことは臨床的にも重要であると思われる。

\section{引用文献}

1） $\mathrm{TDX}^{\mathrm{TM}}$-ジゴキシン「アボット」, 血中ジゴキシン 測定用キット取扱説明書, ダイナボット社, 東京 (1996).

2) アキシムジゴキシンダイナパック ${ }^{\mathrm{TM}} \cdot \mathrm{NPT}$, 血中 ジゴキシン測定用キット取扱説明書, ダイナボッ 卜社, 東京(1998)。

3） ACS : Centaur 専用試薬，ケミルミ ACS-ジゴキシ ンI取扱説明書，バイエルメディカル，東京 (1999).

4) H. M. E. Azzazy, S. H. Duh, A. Maturen, E. Schaller, L. Shaw, et al., Multicenter study of Abbott AxSYM $^{\circledR}$ Digoxin II assay and comparison with 6 methods for susceptibility to digoxin-like immunoreactive factors, Clin. Chem., 43, 1635-1640(1997).

5) P. Datta, V. Hinz and G. Klee, Comparison of four digoxin immunoassay with respect to interfence from digoxinlike immunoreactive factors, Clin. Biochem., 29, 541-547(1996).

6) P. Datta, L. Xu, S. Malik, D. Landicho, L. Ferreri, K. Halverson, P. V. Roby, A. M. Zebelman, M. A. Kenny, Effect of antibody specificity on results of selected digoxin immunoassays among various clinical groups, Clin. Chem., 42, 373-379(1996).

7) A. Dasgupta and O. Trejo, Suppression of total digoxin concentrations by digoxin-like immunoreactive substances in the MEIA digoxin assay, Am. J. Clin. Pathol., 111, 406-410(1999).

8) J. J. Miller and R. Valdes, Jr, Approaches to minimizing interfence by cross-reacting molecules in immunoassays, Clin. Chem., 37, 144-153(1991).

9) A. Dasgupta and P. Datta, Rapid defection of cardioactive bufalin toxicity using fluorescence polarization immunoassay for digitoxin, Ther. Drug Monit., 20, 104-108 (1998).

10) H. M. A. M Qazzaz and R. Valdes, Jr, Simultaneous isolation of endogenous digoxin-like immunoreactive factor, ouabain-like factor, and degrycosylated conge- 
ners from mammalian tissues, Arch. Biochem. Biophys., 328, 193-200(1996).

11) C. De. Angelis, M. Riscazzi, R. Salvini, A. Piccoli, C. Ferri and A. Santucci, Isolation and characterization of a digoxin-like immunoreactive substance from human urine by affinity chromatography, Clin. Chem., 43, 1416-1420(1997).

12) R. F. Pasternack, J. I. Goldsmith, S. Szep and E. J. Gibbs, A spectroscopic and thermodynamic study of porphyrin/DNA supermolecular assemblies, Biophys.
J., 75, 1024-1031 (1998) .

13) L. Shargel and A. Yu, “Applied Biopharmaceutics \& Pharmacokinetics, $4^{\text {th }}$ edition”, Appleton \& Lange, Inc., New York, 1999, pp. 732-733.

14）全自動血中濃度測定システム $\mathrm{TDX}^{\mathrm{TM}}$ 取扱説明 書，アボット株式会社，東京.

15) R. F. Pasternack and P. J. Collings, Resonance light scattering: a new technique for studying chromophore aggregation, Science, 269, 935-939(1995). 